\title{
Estimation of Economic Value of Agroforestry Systems at the Local Scale in Eastern Sudan
}

\author{
Bashir Awad El Tahir ${ }^{1}$, Akshay Vishwanath ${ }^{2}$ \\ ${ }^{1}$ Freelance Consultant, Agroforestry and Ecosystems Analysis, El Obeid, Sudan \\ ${ }^{2}$ People and Landscapes Programme, Eastern and Southern Africa Regional Office (ESARO), International Union \\ for Conservation of Nature (IUCN), Nairobi, Kenya \\ Email: eltahirba48@gmail.com
}

Received 21 September 2015; accepted 24 November 2015; published 27 November 2015

Copyright (C) 2015 by authors and Scientific Research Publishing Inc.

This work is licensed under the Creative Commons Attribution International License (CC BY). http://creativecommons.org/licenses/by/4.0/

(c) () Open Access

\section{Abstract}

The objective of this paper is to institute farmers' own perceptions of the on-and off-farm benefits of agroforestry systems (AFS). Using use value approach, this paper presents empirical evidence on the use values of three types of AFS practiced by the refugees and their hosting communities in Eastern Sudan. The total economic value (TEV) was applied as a framework to estimate the ecosystem values of AFS under study. Goods values were estimated using specific market values, while the services values were qualitatively described according to local perceived values of the local communities. Perceived TEV of AFS includes marketable and non-marketable goods and services. The main direct marketable and sustainable high value products include: food, cash crops, firewood, gum, fodder, NTFPs medicine, fodder, and honey. The valuation results reveal that AFS in the project sites have significantly contributed to the livelihoods of the local communities. Overall, the average net direct-use value of marketable products across all sites was estimated at 7,346,000.0 SDG (1,335,636.36 US\$) HH/annum. Gum Arabic alone accounted for $38 \%$, followed by sorghum grain and fodder $35 \%$, and cash crops (sesame) $18 \%$. This value would be many time higher if other indirect values (non-marketable) services such as shade, aesthetic and recreation, environmental protection, biodiversity and carbon sequestration are quantified. The goods and services mentioned above provide sustainable income to the farmer directly and viable benefits to the region indirectly. Hence, AFS in the study sites shows the way to reconcile two conflicting goals: short-term food and livelihood needs with long-term environmental conservation and improvement. The study provides evidence that the high local perceived values of AFS in the study sites constitute a central means of livelihood, whereas its contribution to the local economy. The study stresses the need to quantify the monetary values of non-marketed products to consistently account for resource availability and usage to further sound policy decisions. Tenure security, farmer support services and human capital development were major areas identified for policy development. 


\title{
Keywords
}

\author{
Local Perceived Values, Marketable Products, Natural Products, Gum Arabic, Non-Timber Forest \\ Products
}

\section{Introduction}

Economic valuation is seen as an analytical tool for decision-making intended to compare the advantages and disadvantages of certain scenarios. It can provide decision-makers with useful information for deciding between alternatives or preferred combinations of possible interventions [1]. Economic valuation provides a means for measuring and comparing the various benefits of ecosystems, and can be a powerful tool to aid and improve their wise use and management [1]. It attempts to assign quantitative values to the goods and services provided by environmental resources, whether or not market prices are available. The most important challenge facing developing countries today is how to promote agricultural practices that provide necessary goods and services while conserving natural capital [2]. To design appropriate policies and strategies that encourage sustainable land uses, it is important to recognize the economic value of environmental services and disservices generated by alternative agricultural practices [3]. Policy makers often do not perceive and value these services due to the lack of information about the market prices that reflect the monetary value they provide [3]. Failure to recognize the use and nonuse value of environmental services provided by different land-use systems, such as soil conservation, carbon sequestration, and biodiversity protection, often encourages the implementation of policies that lack incentives for sustainable agricultural practices [3]-[5].

The concept of ecosystems services (ES) has become an important model for linking the functioning of ecosystems to human welfare [6]-[8]. Generally, ecosystem services are the benefits people obtain from ecosystems [6] [9]-[11]. These benefits can be direct or indirect, tangible or intangible and they can be provided locally and/or at broader scales. Nonetheless, ecosystem services can be defined in various ways dependent on scale and perspective [12]. Also, they can be localized or scattered and are of crucial importance to future generations, making measurement particularly hard [8]. One important aim of the Millennium Ecosystem Assessment (MEA) is to analyze and as much as possible quantify the importance of ecosystems to human well-being in order to make better decisions regarding the sustainable use and management of ecosystem services.

Based on the [6] [10] ecosystem functions and services can be grouped into four primary categories: 1) Production functions (or provisioning services) consist of the processes that combine and change organic and inorganic substances through primary and secondary production into goods that can be directly used by mankind; 2) Regulation functions (or regulating services) relate to the capacity of natural and semi-natural ecosystems to regulate essential ecological processes and life support systems through biogeochemical cycles and other biosphere processes. In addition to maintaining ecosystem (and biosphere) health, they provide many services with direct and indirect benefits to humans such as clean air, water and soil, nutrient regulation, disturbance prevention, biological control and pollination; 3) Information functions (or cultural services) are those services that contribute to human mental well-being. Major categories of cultural services associated with forests are aesthetic and recreational use, spiritual and religious services and importance to cultural heritage, and 4) Habitat functions (or supporting services) relate to the importance of ecosystems to provide habitat for various stages in the life cycles of wild plants and animals, which, in turn, maintain biological and genetic diversity and evolutionary processes.

The valuation of ecosystem services has been receiving increasing attention from various society sectors as a way of providing more concrete data on the value and importance of biodiversity and ecosystems to populaces [4] [5] [10]. The quantification of economic values can, and regularly does, provide useful information for public decisions, especially when the limitations as well as the strengths of the values are recognized [5]. Accurate estimation of ecosystem service values allows the incorporation of otherwise un-quantified values into dominant decision-making frameworks such as benefit cost analysis, economic impact assessments and regulatory impact statements, along with more readily quantified financial costs and benefits [10]. This can better inform decisionmakers about the genuine costs and benefits associated with environmental resources, increasing the efficiency and effectiveness of decisions about their protection or otherwise [10]. 
There are various valuation methods adapted to estimate different types of values. These include that ecosystems directly or indirectly support people's own consumption (use value) or that they support other people or species' own consumption (non-use value) [4] [5] [10]. Despite the existence of valuation methods adapted to different types of values, only provisioning services are routinely valued, while the value of other services, such as supporting, cultural and regulating, is more difficult to assess because the benefits that people derive from these services (willingness of people to pay for these services-which are not privately owned or traded)-frequently cannot be directly observed or measured and usually it is not traded [4] [5] [10].

Various studies have been conducted to estimate the ecosystems value of natural forests. The ecosystem goods and services associated with forests have been reviewed by, amongst others, [6] [13]-[15]. By using a mix of valuation methods, based on over 100 case studies, [11] came to a conservative estimate that the total economic value of native forests is, on average, between US\$300 and 2000/ha/year. Regarding agroforestry systems very few studies are being conducted. [10] have estimated the economic values of local goods and services provided by planted forests in selected villages in Northern India. The total value of the forest service's amount to (US\$477) per annum, which is amounting to around (80\%) of the average annual income in the area, which is about US\$638/HH/year.

To analyze the economic value of ecosystems, the concept of Total Economic Value (TEV) has become a framework widely used for quantifying the utilitarian value of ecosystems [4] [5] [9] [16]. This framework normally dis-aggregates TEV into two categories: use values and non-use values. Use values comprise three elements: direct use, indirect use and option values. It is also known as the extractive, consumptive or structural use value and derives mainly from goods that can be extracted, consumed or enjoyed directly [17]. Indirect use value is also known as the non-extractive use value, or functional value and derives mainly from the services provided by the environment [17]. Option value is the value attached to maintaining the option to take advantage of the use value of something at a later time. Some authors also distinguish quasi option value, which derives from the possibility that even though something appears unimportant now, information received later might lead us to re-evaluate it [17]. Non-use values as the name states, derives from benefits the environment may provide when it is not used in any way. In many cases, the most important benefit of this kind is existence value; the value people derive from the knowledge that something exists even if they never plan to use it [4].

Agroforestry, the intentional growing of trees and crops in interacting combinations, began to attain prominence in the late 1970s, when the international scientific community embraced its potentials in the tropics and recognized it as a practice in search of science [18]. The benefits of agroforestry are both economic and environmental [19] [20] [21]. Development and sponsorship of agroforestry systems and commercialization of the natural products and services (NPs \& S) emanating from them have been widely promoted as an approach to rural development and poverty elevation in many developing countries. Increased donor investments in the development of AFS to increase income; reduce poverty as well as conservation of natural resource and biodiversity, have been the main focus of many development agencies worldwide. It was unanimously acknowledged that agroforestry can address issues such as poverty, food security, sustainable development and climate change [19] [22] [23]. Besides delivering goods for markets, such as food, wood, fiber and fuel, agroforestry systems also provide non-market services, such as recreation and amenity values, habitats for biodiversity, landscape maintenance and several regulation services [7] [20] [24].

The International Union for Conservation of Nature (IUCN) has been supporting environmental restoration and poverty reduction efforts in Eastern Sudan since 2004. Securing rights and restoring lands for improved livelihoods in Eastern Sudan project (SRRLIL) is being implemented in partnership with the Forest National Corporation (FNC). The project aims to support the most vulnerable groups (women, marginalized, pastoralists) to improve their livelihoods through more secure rights, benefits from restoration activities and niche markets opportunities, and more generally in their empowerment to better make and negotiate their case at all levels. Agroforestry was perceived and promoted as one favored land use management option to resolve this situation. Over the past few years AF has been adopted by SRRLIL project in Eastern Sudan as one of the integrated natural resource management interventions for addressing various environmental and socio-economic problems emanating from land degradation.

The establishment of agroforestry systems, however, is expensive in terms of labor an[25]d capital inputs, which may discourage their widespread adoption [25]. The value of these systems depends not only on the market prices of its direct uses, but also based on other indirect uses they provide and that cannot be traded on some kind of market. Although AFS as an integrated land use management systems in the study sites have been in- 
troduced by IUCN and its partners for the livelihood enhancement and enterprise development; empirical estimates of its benefits to local communities and the region are lacking. Furthermore, the generation of benefits from the natural products and services (NPs \& S) derived from AFS to rural producers, as well as the promotion and development of sustainable market linkages and instruments in the region are not well documented. In view of this situation, the objective of this paper was, therefore, to contribute to better understanding of the on-farm benefits of AFS on local communities livelihoods as well as the likely off-farm benefits and to institute farmers' own perceptions in the study sites in order to guide policy decisions in forest management.

\section{Materials and Methods}

\subsection{Study Area}

Eastern Sudan comprises three States (the Red Sea, Kassala and Gedarif), and covers an area of 336,489 $\mathrm{km}^{2}$ with a population of 4.5 million people, that is $21 \%$ of the Sudan population. Over the past years, the region suffered from many circumstances that crippled its development including economic deterioration, drought and desertification cycles, food gaps and diseases. Eastern Sudan stands in an important strategic location and shares borders with four countries including Egypt in the north, Eritrea and Ethiopia on the east and Saudi Arabia across the Red Sea coast (Figure 1).

The project sites (Mefaza and Hawata) and (Kilo 26 and Shagarab) are located in Gedarif and Kassala states, respectively. Gedarif state lies between longitudes $33^{\circ} 34^{\prime \prime} \mathrm{E}$ and $37^{\circ} \mathrm{E}$ and latitudes $12^{\circ} 40 \mathrm{~N} \mathrm{~N}$ and $15^{\circ} 45^{\prime \prime} \mathrm{N}$ with an area of $71,000 \mathrm{~km}^{2}$ (16.9 million feddan)., while Kassala lies between latitudes $14^{\circ} 29 " \mathrm{~N}$ and $17^{\circ} 13^{\prime \prime} \mathrm{N}$ and longitudes $34^{\circ} 13^{\prime \prime} \mathrm{E}$ and $37^{\circ} 02$ "E with an area of about $72,000 \mathrm{~km}^{2}$.

The dominant soils are the dark, heavy, deep clay which crack when they are dry and becomes impervious when wet, with low infiltration capacity. The two states lie within the dry to dry sub-humid zone, with annual rainfall ranging from $150 \mathrm{~mm}$ in northern Kassala State to about $850 \mathrm{~mm}$ in southern Gedarif State. Rainfall is erratic, variable and is almost all confined to the period July-September. The natural vegetation has been classified as semi-desert in the north, low woodland savannah in the center and high woodland savannah in the south [26]. The natural vegetation is invaluable for grazing and forest products. The Eastern Region in general is

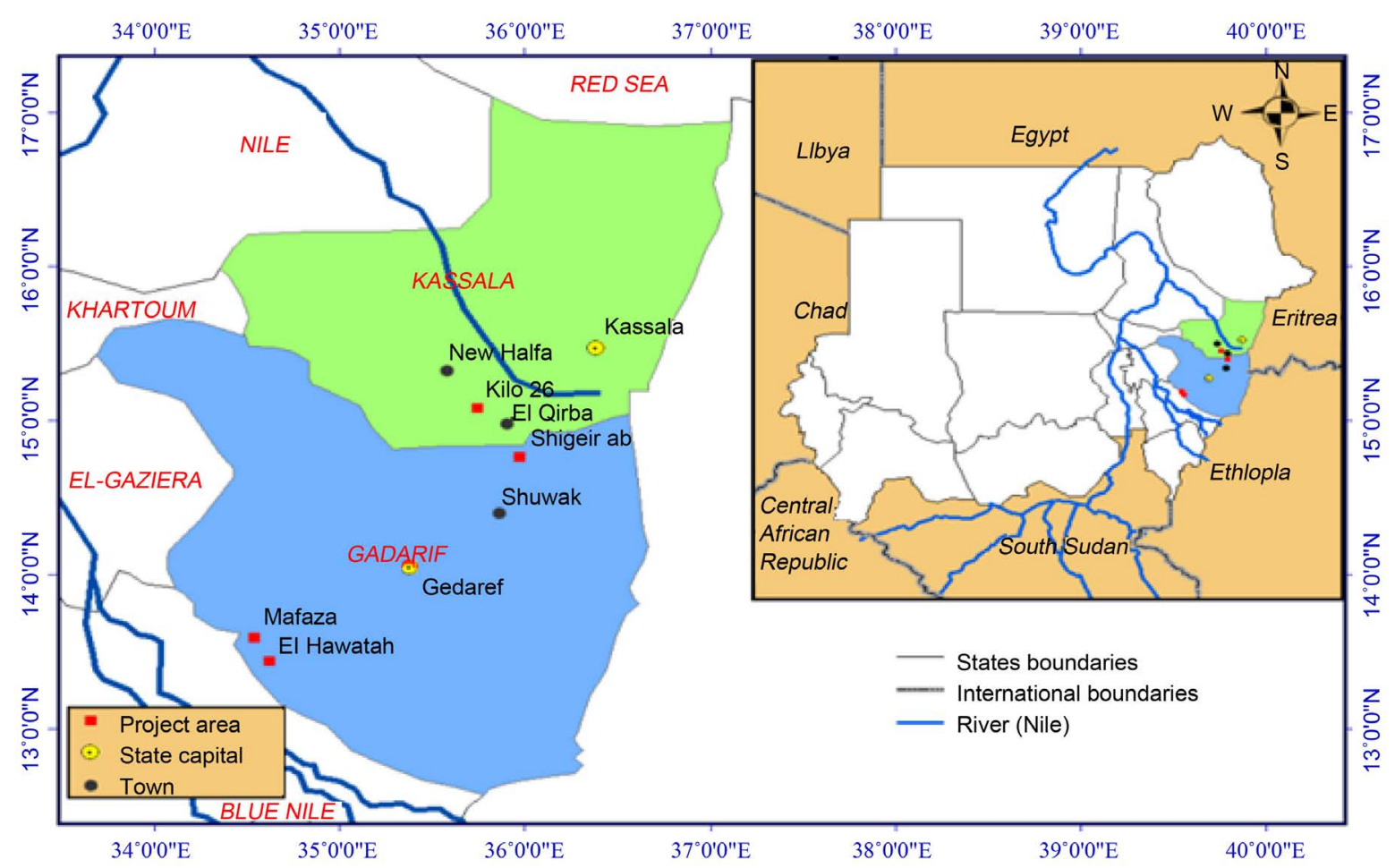

Figure 1. Location of Gedarif and Kassala states and project sites. 
dominated by sedentary cultivators and nomads. Although most of the people practice a mixture of several different land use types, the main land use types are 1) Small-scale rain-fed cultivation, mainly sorghum and sesame; 2) Large-scale rain-fed cultivation. This is mainly mechanized farms practiced on the clay plains of the Gedarif area. Main crops are sorghum and sesame.

\subsection{Study Sites}

The project sites (Mefaza and Hawata) and (Kilo 26 and Shagarab) are located in Gedarif and Kassala States, respectively (Figure 1). According to the baseline survey [27] and the field study, the sites vary in terms of population, area coverage and potentials. In Hawata the project works with resident communities in Khalifaand Hai Al-Hijra villages with a population of 622 and 440 households, respectively. In Mefaza two villages viz Banat Sharej and Hemura are also covered by the project activities, with populations of 520 and 780 households, respectively. The official documents of COR, Khashm El Girba show that about 5599 heads of households' refugees live in Shagarabs three camps. Shagarabs camps lie at a distance of $23 \mathrm{Km}$, SE of Khashm El Girba town and belong to Wad Alhilaew Locality. The same documents reports that about 2110 heads of households of refugees live in Kilo 26 camp. This camp lies to the north-west of Khasm El Girba town at a distance of $19 \mathrm{Km}$. and falls within Khashm El Girba Locality.

Agriculture is the main occupation and farmers constitute over 90\% in Mefaza and over 60\% in Hawata [27]. Generally, farms are small in size with average households having a farm size of 5 feddans or less. Femaleheaded household have less farm land than male-headed households. The land is legally owned by the government and their right to it is only usufructuary. Among the refugees in Shagarabs and Kilo 26 camps, agriculture in the form of rain fed cultivation is the dominant seasonal occupation. About $80.2 \%$ of the Shagarab refugees and $68 \%$ in Kilo 26 site practice cultivation of sorghum as their main staple crop and other types of seasonal work. In Shagarab sites communities are operating under a fully traditional pattern of land tenure. The land is legally owned by the government but is under the control of the Lahawin Tribe leaders who claim the ownership of land on behalf of their tribe. The camps residents have the choice to go for both renting and share cropping arrangements. The Lahawin who claim the ownership of the land prefer renting so as to avoid any risk of season failure. The renting value for 5 feddans ranges from 100 to 200 SDG (20 to 40 US\$). However, beside farming, varying proportions of males and females among resident communities and refugees, are also engaged in other occupations, mainly as officials, petty traders, tea and coffee sellers and water fetchers, animal husbandry, teashop attendant, middleman, guard, tailor, nurse, teacher, milk seller, water vendor, carpenter, hut builder, assistant shop laborer and car driver.

The main food crop produced in the project sites is sorghum which is cultivated by almost all farmers. Very few farmers in Hawata and Mefaza grow sesame or groundnuts, while vegetables are mainly grown at Kilo 26. Food insecurity is widely prevalent, emanating from the small farm size, damage of crop by animals, high labor cost, variable climatic conditions and deteriorating soil productivity. Poverty has deprived the communities from their right to basic services, especially education because the families cannot afford to pay the school fees and schooling needs and also because they send their children to the labor market to support the family budget [27]. Environmental degradation, small farm size and declining agricultural productivity have negatively impacted on the living conditions. Main adaptations strategies include selling animals, reducing the number and quantity of meals, increasing female and child labor, emigration of husbands, increasing dependence on animal products, remittances and support from relatives and humanitarian assistance from organizations [27].

There are many tree species in the study sites. The most common tree species found in the landscape include Acacia seyal and Acacia senegal. These are trees used as firewood, Gum Arabic production, boundary markers and are commonly mixed with crops. Biomass is the major source of energy, where about $95 \%$ of the households use firewood, over $85 \%$ use charcoal and about $3 \%$ use gas as sources of energy. It is also estimated that the average annual household consumption is about $19 \mathrm{M}^{2}$ of wood for provision of energy and building material [27]. Because of the limited amount of available dead wood, it is reasonable to assume that this high demand is satisfied by large commercial operations mainly in south Blue Nile State, but also in the southern parts of Gedarif State. This constitutes a serious threat to biological diversity and a challenge for sustainable environmental management [27].

\subsection{Data Collection and Analysis}

Data collection was based on both primary and secondary sources. Primary data were assembled through a house 
hold survey, focus groups discussion, key informant interviews using check list and expert consultation. First, a structured household survey questionnaire was used to collect quantitative data. The collected data were related to the farm and household including family size, source of income, source of energy, plot size and ownership, tree species and density, crops types, main farm inputs and outputs used and the impact of AFS on the household's lifestyle such as direct and direct use values. Second, direct discussions were conducted with farmers who are practicing agroforestry for the qualitative data such as challenges and constraints to AF systems, and policies and regulations needed to support AF enterprises. Third, participant observation was carried out to understand the characteristics of the study sites being researched.

For the household survey a multi-stage random sampling was used in the data collection. The first stage was a purposive sampling of the three prototypes of AFS predominating in the study sites, namely, taungya; rain fed agroforestry and irrigated agroforestry. The second stage was random sampling of farmers involved for administering the questionnaire and group discussion. A list of farmers participating in the three AFS was obtained from the project headquarter office at El Fau, Gedarif State. As stated by the Project Manager, the number of participating farmers in the four sites during the period 2010-2012 was 188 farmers; 60 farmers in each of $M e$ faza, Hawata and Kilo 26 and about 8 farmers in Shagarab site. Based on that, four separate lists contained the names of the farmers involved in the three AFS were prepared with the help of the Project Manager for household interview. About 25 farmers were selected at random from each site: Mefaza, Hawata and Kilo 26, while in Shagarab sites all participating farmers (8 farmers) were selected, making a total of 83 farmers. The information provided by individual farmers was verified through focus group discussions and interviews with key informants, forestry officials and experts consultation.

To analyze the economic value of the AFS, the use value approach was adopted and the TEV framework has been used. Using this method, marketable benefits were identified and quantified using available data, while non-marketable benefits such as shade, soil improvement, soil conservation, climatic amelioration, carbon sequestration and aesthetic and recreation values were identified, but were qualitatively valued based on local perceived values. The main reasons for these were restricted time scale and budget for conducting the consultancy.

Statistical Package for Social Sciences (SPSS) Version 16.0 was used to analyze the data collected using survey questionnaires. Descriptive statistics as means, percentages and frequencies presented as tables, graphs and charts were used for data interpretation.

\section{Results and Discussion}

\subsection{Characteristics of Agroforestry Systems (AFS) in the Study Sites}

Agroforestry systems in the project sites can be categorized into three main systems namely: the taungya; rain fed agroforestry and irrigated agroforestry. The three systems are most commonly practiced to provide livelihood benefits to local inhabitants and widely accepted by FNC for rehabilitation of the degraded forests. Although these land-use systems are distinct economic activities, farmers variously engage in other livelihood activities to supplements their income. For example, during off season farmers in the project sites seek employments or perform some sort of petty trading outside their residences. Moreover, farmers in the project sites rarely keep records of inputs, outputs and prices associated with these types of minor activities and this situation presents a challenge for the comprehensive collection of quality data on each land-use system. The focus of this study is on the potential contribution of the selected AFS to the sustainability of livelihoods of the local communities in the study sites. The three AFS analyzed are described in the following sections.

\subsubsection{Taungya System}

Taungya system is a forest management tool adopted by FNC to be implemented through the Participatory Forest Management (PFM) approach to rehabilitate degraded forests in the Eastern Region. The main objectives were to regenerate and protect reserved forest, while helping vulnerable landless men and women of local communities to earn a living on land under FNC ownership. The system is applied into two forest reserves namely, Wad El Bashir and Um Gira, in Hawata Forest Circle. The production systems are usually operated by smallholder farmers in predetermined areas in the reserved forests. The normal practice involves allotment of 100 feddan to 20 households (5 feddans each) each year on contractual basis. The farmer enjoys the right of using the land for agriculture during the period stated in the contract. Two project sites (Hawata and Mefaza) were in- 
volved in this system. In Shagarab camps FNC offers an area of 100 feddan annually for 50 persons of the Camp residents.

In the initial year of establishment, the project undertakes the responsibility of land preparation and provides farmers with tree seeds and/or seedlings and seeds of agricultural crops and technical assistance. The contracted farmers carry out activities such as planting of seedlings, weeding and the protection of planted area. The main tree species used are Acacia senegal and Acacia seyal. The main crops commonly produced annually are sorghum and sesame. Farmers usually adopt crop rotation, where they rotate sorghum with sesame. Sesame as cash crop is usually cultivated by farmers when they get information that the predicted rainfall will be adequate to support sesame cultivation. In the subsequent seasons the farmers bear the costs of all agricultural activities. Under this system the farmers can use the plot for between 2 - 3 years.

\subsubsection{Rain Fed Agroforestry}

This systems is traditionally practiced by small farmers in the study area e.g. Wad Alhilew village. In these areas farmers cultivate sorghum and other cash crops with A. senegal. In the refugee camps at Shagarab, which fall outside the Acacia senegal ecological zone, households cultivate sorghum with Acacia seyal under taungya systems in the reserve forests, where annually FNC distribute 100 feddans for 50 families. The project has identified and secured lands, service contracts were prepared, singed and stamped with interested beneficiaries (groups and individuals) who performed agroforestry activities under collaborative forest management.

In Shagarab camps, this system is practiced in the government lands secured by IUCN and FNC since 2004 and participation in most of the sites is limited to families. In this system, the tree seedlings used are mainly Acacia seyal. The seedlings are planted at inter- and intra-row spacing of $8 \times 3 \mathrm{~m}$ given a tree density of 175 seedlings per feddan ( 2.4 feddan $=1$ hectare). The system is an alley cropping type of agroforestry and mainly sorghum as food crop is grown between the alleys of the trees. Discussion with the people and subsequent clarification from the project records revealed that rain fed agroforestry system was practiced on land which had a legal status of "village community land". This land which is used to be common land was equitably distributed among refuges, where each family is allotted 2 to 3 feddans.

\subsubsection{Irrigated Agroforestry}

The system is practiced in Kilo 26 on communal lands secured by UNHCR, IUCN and FNC. An area of 88 feddans was established, 50 feddans of which was allocated for the villagers, and the remaining 38 feddans were allocated for the refugees in the camp. The production systems are usually operated by smallholder farmers in an area of 30 feddan under irrigation. About 20 households each have 1.5 feddan to cultivate with agricultural crops according to their preference in strips between forest trees. The plots are fenced with barbed wire.

Similar to taungya and rain fed wood lots, in the establishment phase, the project assists in land preparation and supplies the farmers with essential inputs such as crops seeds, fertilizers and pesticides, irrigation inputs (water pumps, and hose). Farmers were also supplied with forest tree seedlings mainly Acacia. seyal. The selected farmers on the other hand carry out all other activities such as planting of seedlings, weeding and the protection of planted area. Land preparation is carried out using disc plough. It consists of construction of irrigation channels (furrows), and plowing of the strips between channels. Trees are planted on the top of the furrow. Tree planting density was 175 seedlings/feddan (with trees spaced at $3 \times 8 \mathrm{~m}$ ). The main crops grown are sorghum, leafy vegetables, Okra, hot peppers, fodder crops (Abu 70), tomato, and cucurbitaceous crops (e.g. agoor).

For rain fed and irrigated agroforestry, plots are not far from the camps and family labor is utilized for the management of the plots. All members of the household participate in the day to day working of the AFS to varying degrees. Both male and female members of the household participate in both the labor and in the economic decision making processes. Hired laborers are employed according to need. Labor is an increasingly expensive commodity in the study site, and daily wage for male laborers can be as high as 40 SDG per day (approximately \$6) in urban areas. Labor is hired mainly for certain tasks such as gum tapping, weeding and crop harvesting.

\subsection{Socio-Economic Information}

\subsubsection{Household Size and Annual Income}

The official documents reviewed at the project sites showed that about 1062 households live in Hawata (622 in Khalifa and 440 in Hai Al Hijra) and about 1300 households live in Mefaza (520 in Banat Sharig and 780 in 
Hemura). These represent hosting communities. In Shagarab site about 5599 heads of households' refugees live in the three camps and that about 2110 heads of households of refugees live in Kilo 26 camp. Average household size is 8 people, in Mefaza, Shagarab and Kilo 26 and 7 in Hawata (Table 1).

Respondents were asked to indicate their annual income. Table 1 showed that the highest annual income was reported in Mefaza amounting to 11,115 SDG, and the lowest was in Shagarab amounting to 2100 SDG. Annual income in Hawata and Kilo 26 amounts to 6634 and 5693 SDG, respectively. These are equivalent to 31, 18, 6, and 16 SDG per day, in Mefaza, Hawata, Shagarab and Kilo 26, respectively. These figures indicate that the communities in Shagarab earn less money per day and need more support. It is worth noting that adequate income to meet the needs of the households is the major factor in promoting AF adoption and sustainability.

\subsubsection{Households Livelihoods Strategies}

The main household's sources of income are shown in Figure 2. Agriculture including mainly agroforestry is the main source of income for the majority (85.4\%) of the respondents. The main agricultural activities are crop and livestock production, with sorghum grown as a food crop, sesame as a cash crop and a small number of vegetables produced. This indicates that agroforestry systems in the project sites had positive impact on poverty alleviation through its contribution to farmer's income. The second highest source of income was labor (6.7\%). Other sources account for 3.5\%, while animal husbandry and fuel wood sale scored $2.4 \%$ and $2.0 \%$, respectively. Livestock production is mainly in the form of cattle, goats, sheep, and poultry. Households in the project sites practice other income generation activities including, fuel wood and collection and trading of NTFPs such as edible fruits, skilled and unskilled labor, honey production and non-farm activities such as trade/petty trading. Very few of the households receive remittance from relatives working abroad.

\subsubsection{Plot Size and Ownership}

Table 2 shows the area planted, tree species and stocking density. Average farm size was 5 in taungya systems in Hawata and Mefaza, 1.5 in Kilo 26 and 3 feddan in Shagarab. The farm size is considerably larger in "taungya" agroforestry and much smaller in rain fed and irrigated AFS agroforestry. The small farm size in rain fed and irrigated AFS could be attributed to land tenure systems in the study area which was based on the belief that planting trees will mean land rights. Most of the farmers (90\%) interviewed, reported that they do not own land and only have usufructs rights. The land tenure of taungya system is government (FNC) land, while that of rain fed and irrigated AFS was communal land. AFS are not adopted extensively in community managed areas because there is a perception that it will mean the claiming of land rights. Hence, this is limiting the practice. In the taungya system the practice is only being permitted for $2-3$ years and as the land is government reserve so there is no perception of claiming rights. Land ownership is a major problem affecting the study area for a long time.

Table 1. Households size and annual income.

\begin{tabular}{cccc}
\hline Project sites & $\begin{array}{c}\text { Total number of household } \\
\text { (person) }\end{array}$ & $\begin{array}{c}\text { Household size } \\
\text { (person) }\end{array}$ & $\begin{array}{c}\text { Annual income } \\
\text { (SDG) }\end{array}$ \\
Mefaza & 1300 & 8 & 11,115 \\
Hawata & 1042 & 7 & 6634 \\
Shagarab & 5599 & 8 & 2100 \\
Kilo 26 & 2110 & 8 & 5693 \\
\hline
\end{tabular}

Table 2. Average AF plot size, tree species and stocking density.

\begin{tabular}{cccccc}
\hline Project Sites & Area (feddan) & Trees stocking density (tree) & \multicolumn{2}{c}{ Main tree species (\%) } \\
\hline Mefaza & 5 & & A. senegal & A. seyal & Mixture \\
Hawata & 5 & 350 & 39.3 & 3.6 & 57.1 \\
Shagarab & 3 & 350 & 39.3 & 0 & 60.7 \\
Kilo 26 & 1.5 & 175 & & 100 & \\
\hline
\end{tabular}




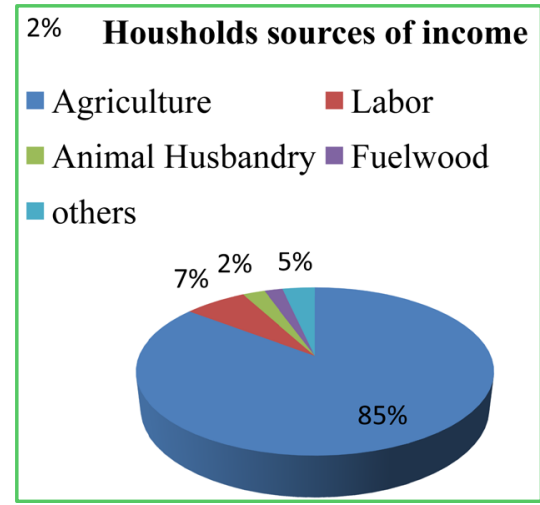

Figure 2. Household sources of income.

Land is the primary source of livelihood for the majority of the people in the study sites. Land distribution is an important issue in rural development, the size of it also dictates its utilization and where land is insufficient to support the basic needs of a family, there is a tendency for communities to encroach into protected areas such as forest reserves.

\subsection{Total Economic Values of Goods and Services from AFS in the Project Sites}

Estimating the economic values of AFS is challenging. The systems provide use and non-use values, the later however are difficult to measure quantitatively due to greatest uncertainty attached to them. Perceiving AF as an ecosystem that provide market and non-market goods and services, the TEV may be considered as the most widely used framework to identify and quantify the contribution and values of ecosystems services to human wellbeing [5] [11] [28]. Hence, in this study the TEV was applied here as a framework to estimate the ecosystem values of AFS under study. The two categories of values (direct and indirect values) of TEV are used to determine the total valuation of AFS in the study sites. The following sections present the main goods and services provided by AFS and that generate direct and indirect use values to local communities.

\subsubsection{Quantities and Use Values of Direct Consumptive Products}

Participants were asked to identify direct consumptive uses for maintenance and sustainability of their livelihoods from the AFS plots in the project sites. This was complemented by simple scoring from 1 - 5 to investigate the relative weight of the direct consumptive uses. The major categories identified were food crops, cash crops, gum Arabic, firewood, livestock feed (sorghum fodder), honey, NTFPs and traditional medicine (Table 3). In addition to these, participants have also emphasized that AFS provided them with other products such as dyeing, hand crafts, building materials and household utensils, but in very small amounts. Categories and scores of products of direct use values are summarized in Table 3.

Table 3 shows that participants in the four sites have mentioned a diversity of products emanate from AFS which contribute to their subsistence as well as maintenance and sustainability of their livelihoods. This is in line with the facts that AF can significantly contribute to diversification of outputs. According to [29], one of the most important functions of AFS is the diversity of outputs, as trees in AFS can provide tree products for on-farm consumption or sale such as wood, fuel wood, foods, medicine, gum, etc.

The table also shows that, on average, both men and women groups gave the highest scores to the contribution of AFS to food crops, firewood, livestock feeds and gum Arabic. It was only in Hawata and Mefaza that sesame as a cash crop was mentioned and scored highest, while honey as a product from AF was only mentioned in Kilo 26. Women groups gave the highest score to food, firewood and NTFPs as the most essential activities for their livelihoods. Livestock feeds scored higher in Shagarab and Kilo 26. This could be due to the fact that refugees in the two camps own a large number of livestock and the crops and tree fodders they obtain from AF plots contribute significantly to this use. Traditional medicine scored low compared to other products which could mainly be due to the low diversity of tree species in the AF plots and participants have limited use only to the main tree species in their plots (A. senegal and A. seyal).

1) Quantities and use values of direct consumptive used products from AFS. 
The questionnaire survey was used to quantify the household use and sale of marketable AF products. The information gleaned during focus group discussion and key informants were used to verify data supplied by the respondents.

Table 4 shows the mean annual quantities of directly used marketable products. The annual direct worth for each product was calculated by multiplying mean annual household consumption (for subsistence and sale) by current local market prices. The annual direct use worth of utilizing of the different marketable products per household per year in the project sites are presented in Table 5 .

Food: Sorghum (Sorghum bicolor (L). Monech) is a main staple crop in the study sites. Beside its use as energy source to human consumption, it draws its great value as source of grain and straw that is used for animal feed. In very good cropping season such as 2012, average yield of sorghum per feddan amounted to 335, 300 and $1000 \mathrm{~kg} /$ feddan in Taungya, Rain fed and Irrigated AFS, respectively. The higher yields in irrigated AFS compared with other systems could be attributed to good management due to small size of land holdings and the availability of moisture due to application of irrigation. The slightly higher sorghum yields under taungya compared with rain fed AFS might be attributed to the high soil fertility and enhancement of microclimate under forest sites. While under rain fed systems despite enhancement of soil fertility, low and erratic rainfall and poor management could be cited as the main causes of low yields.

The actual quantities of food crops obtained and used by different households in the project sites for domestic consumption averaged $1587.5 \mathrm{~kg} / \mathrm{HH} / \mathrm{annum}$. Participants in Mefaza and Hawata use the largest amounts (1675 kg/HH/annum), while Shagarab and Kilo 26 use the lowest (1500 kg/HH/annum). The annual direct use worth

Table 3. Categories and scores of products of direct use values from $\mathrm{AFS}^{* *}$.

\begin{tabular}{|c|c|c|c|c|c|c|c|c|c|c|}
\hline \multirow{3}{*}{ Direct used categories } & \multicolumn{8}{|c|}{ Project sites } & \multirow{2}{*}{\multicolumn{2}{|c|}{ Average }} \\
\hline & \multicolumn{2}{|c|}{ Mefaza } & \multicolumn{2}{|c|}{ Hawata } & \multicolumn{2}{|c|}{ Shagarab } & \multicolumn{2}{|c|}{ Kilo 26} & & \\
\hline & M & $\mathrm{F}$ & M & F & $\mathrm{M}$ & $\mathrm{F}$ & M & $\mathrm{F}$ & M & $\mathrm{F}$ \\
\hline Food crops & 5 & 5 & 5 & 5 & 5 & 5 & 5 & 5 & 5.0 & 5 \\
\hline Cash crops & 5 & 4 & 5 & 3 & 0 & 0 & 0 & 0 & 2.5 & 1.8 \\
\hline Firewood & 3 & 5 & 4 & 5 & 5 & 5 & 5 & 5 & 4.3 & 5.0 \\
\hline Gum Arabic & 5 & 4 & 5 & 3 & 3 & 2 & 2 & 0 & 3.8 & 2.3 \\
\hline Livestock feed & 3 & 3 & 4 & 3 & 5 & 4 & 5 & 4 & 4.3 & 3.5 \\
\hline NTFPs & 4 & 5 & 3 & 5 & 3 & 4 & 3 & 4 & 3.3 & 4.5 \\
\hline Honey & 0 & 0 & 0 & 0 & 0 & 0 & 4 & 4 & 1.0 & 1.0 \\
\hline Traditional medicine & 4 & 2 & 5 & 2 & 3 & 2 & 2 & 1 & 3.5 & 1.8 \\
\hline
\end{tabular}

${ }^{* *} \mathrm{M}$, denotes males and $\mathrm{F}$, denotes female; (number indicates the scores).

Table 4. Mean annual quantities of household consumption of directly used products.

\begin{tabular}{|c|c|c|c|c|c|c|}
\hline \multirow{2}{*}{ Categories } & \multirow{2}{*}{ Units } & \multicolumn{4}{|c|}{ Project sites } & \multirow{2}{*}{ Average } \\
\hline & & Mefaza & Hawata & Shagarab & Kilo 26 & \\
\hline Food crops (sorghum) & Kg & 1675 & 1675 & 1500 & 1500 & 1587.5 \\
\hline Cash crops (Sesame) & $\mathrm{Kg}$ & 1800 & 2000 & 0 & 0 & 950 \\
\hline Firewood & M3 & 8 & 7 & 10 & 9 & 8.5 \\
\hline Gum Arabic & $\mathrm{Kg}$ & 500 & 400 & 350 & 10 & 315 \\
\hline Livestock feed & Kg & 2750 & 2750 & 2389 & 2850 & 2684.75 \\
\hline NTFPs & $\mathrm{Kg}$ & 30 & 40 & 50 & 15 & 33.75 \\
\hline Honey & $\mathrm{Kg}$ & 0 & 0 & 0 & 4 & 1 \\
\hline Traditional medicine & $\mathrm{Kg}$ & 0.87 & 1.35 & 2.45 & 2.6 & 1.8175 \\
\hline
\end{tabular}


Table 5. Mean direct use values (SDG/household/year) of consumptive products.

\begin{tabular}{|c|c|c|c|c|c|c|}
\hline \multirow{2}{*}{ Direct use values } & \multicolumn{4}{|c|}{ Project sites } & \multirow{2}{*}{ Average } & \multirow{2}{*}{$\%$} \\
\hline & Mefaza & Hawata & Shagarab & Kilo 26 & & \\
\hline Food crops & 2512.5 & 2512.5 & 2250.0 & 2250.0 & 2381.3 & 13 \\
\hline Cash crops & 6300.0 & 7000.0 & - & - & 3325.0 & 18 \\
\hline Firewood & 1200.0 & 1050.0 & 1500.0 & 1350.0 & 1275.0 & 7 \\
\hline Gum Arabic & $11,000.0$ & 8800.0 & 7700.0 & 220.0 & 6930.0 & 38 \\
\hline Livestock feed & 4125.0 & 4125.0 & 3583.5 & 4275.0 & 4027.1 & 22 \\
\hline NTFPs & 300.0 & 400.0 & 500.0 & 150.0 & 337.5 & 2 \\
\hline Honey & - & - & - & 320.0 & 80.0 & 0 \\
\hline Traditional medicine & 4.4 & 6.8 & 12.3 & 13.0 & 9.1 & 0 \\
\hline Total (SDG) & $25,441.9$ & $23,894.3$ & $15,545.8$ & 8578.0 & $18,365.0$ & 100.0 \\
\hline Total (US\$) & 5782.2 & 5430.5 & 3533.1 & 1949.5 & 4173.8 & \\
\hline
\end{tabular}

of utilizing food crops from AFS, averaged across all households, was 2381.3 SDG/annum. The total annual value ranged from 2512.50 in Hawata and Mefaza to 2250.00 SDG in Shagarab and Kilo 26. This variability could be attributed to low yields per feddan in Shagarab and to the small size of AF plots in Kilo 26.

Cash crops: Sesame is the main cash crop cultivated under taungya systems in Hawata and Mefaza. The crop is not cultivated under rain fed or irrigated AFS, because the environmental conditions (e.g. rainfall) is not favorable for its growth. However, it was stated by the respondents that productivity of both crops were higher in good rainy seasons such as 2009 and 2012, while it was average in 2011 and low in bad seasons such as 2010.

Vegetable crops for local consumption and for sale are grown under irrigated agroforestry in Kilo 26. They include leafy vegetables, beans, and some vegetables from the cucurbitaceous family including pumpkin, zucchini, tomato, eggplants and hot pepper. Because of difficulties to estimate quantities of vegetable crops due to variability of crops cultivated and seasons, only sesame was accounted for in this study.

The quantities of sesame used by participants averaged $950 \mathrm{~kg} / \mathrm{HH} / \mathrm{annum}$. The largest amounts were in Hawata and the lowest were in Mefaza. Sesame is the main cash crops cultivated under taungya systems in these two sites. Overall, the average yields amounted to $360 \mathrm{~kg} /$ feddan. The annual direct use worth of utilization of cash crops averaged across all households was 3325.00 SDG HH/annum. The total annual values were 6300.00 SDG HH/annum in Mefaza and 7000.00 SDG HH/annum in Hawata.

Fuel wood: One of the most important way in which AFS contribute to household life, is provision of firewood. The quantities of fuel wood used by households averaged $8.5 \mathrm{~kg} / \mathrm{HH} / \mathrm{annum}$. The quantities ranged from 10 in Shagarab to $7 \mathrm{~kg} / \mathrm{HH} / \mathrm{annum}$ in Hawata. The average annual direct use worth of fuel wood across all households was $1275.00 \mathrm{SDG} / \mathrm{HH} / \mathrm{annum}$. The total annual values ranged from $1500.00 \mathrm{SDG} / \mathrm{HH} / \mathrm{annum}$ in Shagarab to 1050.00 SDG/HH/annum in Hawata.

Fuel wood is the most common source of energy that farmers in the study site use for cooking as in other parts of the region. It was estimated that the average annual household consumption is about $19 \mathrm{M}^{3}$ of wood for provision of energy and building material [27]. Participants mentioned that fuel wood is obtained from many sources, including trees in own plots, natural forests, buying from private sources. Energy consumption from these sources varied with agroforestry types. Over $90 \%$ of the fuel-wood need of the farmers who had adopted rain fed agroforestry systems in Shagarab sites and irrigated AFS in Kilo 26 sites was fulfilled from agroforestry plots. While about $50 \%$ to $60 \%$ of the fuel-wood needs of the farmers who had adopted taungya systems in $\mathrm{Me}$ faza and Hawata sites were fulfilled through purchasing from wood traders. This is mainly because in Mefaza and Hawata sites farmers practice taungya agroforestry in reserved forests and were not allowed to cut or pollard trees, but only uses dead wood and dry branches. Not only this but also agroforestry plots were far from their residence. Besides fuel-wood, there were some other energy sources that farmers used in the study sites. These sources included biogas, liquefied petroleum gas (LPG) and in some cases cow dung cakes.

Participants in Shagarab and Kilo 26 stated that AFS supply some of their domestic fuel wood demands. 
However, they stressed that they only use dead wood and branches in large quantities for domestic consumption due to the short distances for collection and availability. They further added that in many occasions they extracted some building materials from their AF plots. However, participants from Mefaza and Hawata sites mentioned that they use low amounts of fuel wood from their plots because AF plots were far from their residence and only small amount can be transported from plots.

Gum Arabic: Participants were asked if they were practicing gum production in their AF plots. All participants $(100 \%)$ mentioned that they were practicing gum production to some degree. However, about $89.3 \%$ in Mefaza and 63.2\% in Hawata indicated that they were practicing gum production. In these two sites, households collect gum from their plots inside the reserved forests, based on simple contract signed between the farmer and FNC. The percentage of households who collect gum Arabic in Shagarab and Kilo 26 amounted to 35.7\% and $6.8 \%$, respectively (Figure 3).

The apparent difference in gum production activities between the different systems could be attributed to the fact that, under rain fed and irrigated AFS, the main tree species is Acacia seyal, while under taungya systems in Mefaza and Hawata sites Acacia senegal is most dominant tree species. Beside the low tree density per farmer plots in the former systems gum yield per tree is small and fetch lower prices (250 SDG/Kantar) at the time of the study (February, 2013), compared to collected gum from Acacia senegal (500 SDG/Kantar). Not only this, but also farmers practicing rain fed and irrigated AFS lack the skill of gum tapping. These of course could be the main reasons that deter farmers from collecting gum Arabic. A tree product such as gum Arabic from AF plots is an incentive to promote adoption and management of AFS in the study sites. Hence, for sustainable production, training on gum tapping, offering a better price for gum Talha, and founding exceptional producers groups will encourage farmers to collect and increased gum production from rain fed and irrigated systems.

The quantities of gum Arabic for annual consumption and sale used by households averaged $315 \mathrm{~kg} / \mathrm{HH} / \mathrm{annum}$. The amount ranged from $500 \mathrm{~kg} / \mathrm{HH} / \mathrm{annum}$ in Mefaza to $10 \mathrm{~kg} / \mathrm{HH} / \mathrm{annum}$ in Kilo 26. The average annual direct use worth of gum Arabic across all households was 6930.0 SDG /HH/annum. The total annual values ranged from 11,000.0 SDG/HH/annum in Mefaza to 220.0 SDG/HH/annum in Kilo 26.

Livestock feeds: One of the major bottlenecks for livestock production in the study sites is the absence of sufficient feed sources. The contribution of AFS in fulfilling the demand for livestock fodder and browsing materials was emphasized by the majority of participants in the study sites. Participants in Mefaza and Hawata sites mentioned that they own very few animals. Because there are no open natural pastoral lands, their animals feed on the scanty vegetation around the settlements, crop residues and purchased fodder. They use crop fodder harvested from their AF plots and very rarely take their animals to feed on the remaining crops residues in their plots. However, participants in Shagarab and Kilo 26 stated that beside the crops fodders obtained from their crops they quite often rear their animals inside their plots to feed on tree leaves, pods and flowers and the residues of sorghum stumps and leaves.

The mean annual quantity of fodder used by the households in the study sites averaged across the four sites was $2685 \mathrm{~kg} / \mathrm{HH} / \mathrm{annum}$. The higher amount was $2850 \mathrm{~kg} / \mathrm{HH} / \mathrm{annum}$ in Kilo 26, and the lowest was in Shagarab amounted to $2389 \mathrm{~kg} / \mathrm{HH} / \mathrm{annum}$. The higher amounts in Kilo 26 could be attributed to irrigation facilities. The average annual direct use worth of livestock feed across all households was 4027.1 SDG /HH/annum. The total annual values ranged from 4275.0 SDG/HH/annum in Kilo 26 to 3583.5 SDG/HH/annum in Shagarab.

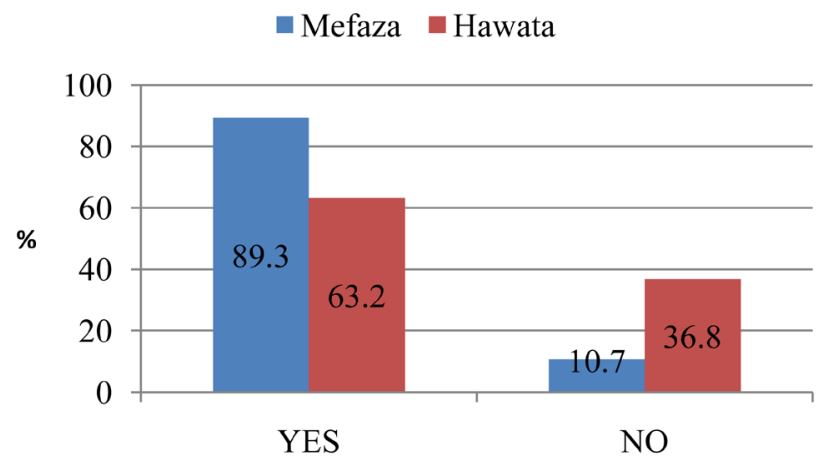

Figure 3. Participants who practice gum Arabic production in the project sites. 
Non-timber forest products (NTFPs): The use of NTFPs by the households in the project sites was very small. The most common products include fibers, tree seeds and flowers. However, the NTFP that of significant importance is tree seeds. Farmers annually collect tree seeds and sell them to FNC and other buyers. The amount used averaged $15 \mathrm{~kg} / \mathrm{HH} / \mathrm{annum}$ across all household, and ranged from $50 \mathrm{~kg} / \mathrm{HH} / \mathrm{annum}$ in Mefaza to $15 \mathrm{~kg} /$ HH/annum in Kilo 26. The annual direct use worth of utilization of NTFPs averaged across all households was $337.50 \mathrm{SDG} / \mathrm{HH} / \mathrm{annum}$. The total annual values ranged from $500.00 \mathrm{SDG} / \mathrm{HH} / \mathrm{annum}$ in Shagarab to 150.00 SDG/HH/annum in Kilo 26. This agrees with [30] who stated that in Africa NTFPs tend to have minor contribution to household income.

Honey: This enterprise was introduced recently as pilot endeavor to further improve households' income in other sites. Honey production as an agroforestry product is only extracted by household in Kilo 26. The quantity of honey used by different households was $4 \mathrm{~kg} / \mathrm{HH} / \mathrm{annum}$. The annual direct use worth of utilization of honey, across all households was $80.00 \mathrm{SDG} / \mathrm{HH} / \mathrm{annum}$. The total annual value was $320.00 \mathrm{SDG} / \mathrm{HH} / \mathrm{annum}$ in Kilo 26.

Traditional medicine: Mean annual household consumption of traditional medicine averaged $2.0 \mathrm{~kg} / \mathrm{HH} /$ annum across all households in the four sites. The quantities used ranged from $0.87 \mathrm{~kg} / \mathrm{HH} / \mathrm{annum}$ in Mefaza to $2.6 \mathrm{~kg} / \mathrm{HH} / \mathrm{annum}$ in Kilo 26. The highest quantities were reported in Shagarab and Kilo 26 which amounted to 2.45 and $2.6 \mathrm{~kg} / \mathrm{HH} / \mathrm{annum}$, respectively.

The annual direct use worth of utilization of traditional medicine, across all households was $9.1 \mathrm{SDG} / \mathrm{HH} /$ annum. The total annual values ranged from 13.00 SDG/HH/annum in Kilo 26 to 4.4 SDG/HH/annum in Mefaza. The main causes for such difference between the four sites could be due to the fact that communities in Hawata and Mefaza use the medical institutions which are geographically accessible to the respective communities. Households use traditional medicine such as pods, leaves, tree barks and gums to cure some diseases such as Malaria and other ailments.

Over all, the average net direct-use value of marketable products from AFS across all sites was estimated at 18,365.00 SDG/HH/annum. Gum Arabic alone accounted for 38\%, followed by sorghum grain and fodder 35\%, and then cash crops $18 \%$. This shows the significant contribution of AFS to food security and income improvement of the local communities. This is in line with [31] who reported that trees in agroforestry can supply farm households with a wide range of products for domestic consumption or for sale, including food, medicine, fuel wood, nuts, fruits, building materials, timber and livestock's feeds. Agroforestry also helps maximizing productivity, creating jobs and income in rural areas, and safeguarding sustainability [32].

\subsubsection{Indirect Use Values}

In dealing with the TEV or full values of ecosystem both marketable goods (for subsistence and sale) and nonmarketable goods and services should be considered [33]. The previous section assessed the marketable direct use values of selected goods and services emanated from AFS based on their importance for local people. These represent the larger subcategory of the direct consumptive use values. This section complements the monetized direct use values of AFS by extending the scope further into the locally perceived full values.

In answering the question "What are the values that AFS provide beside their contribution to the household maintenance?” Participants mentioned the following basic socio-cultural and environmental values:

Shade: Participants explained that they see AFS as similar to close forest or a house; because they provide shade during cultivation and livestock herding. They expressed their concerns about the current deforestation in the area. Some participant at Shagarab and Kilo 26 sites mentioned that before tree planting in the area we used to go to very far places to herd our livestock and find rest places. They added that in their agroforestry plots they find both a shade and feeding places that are not far from their homesteads.

Climatic amelioration: Participants also mentioned that the occurrence of rains was seen as one of the main benefits of trees. During FGD many respondents have the perception that trees could attract clouds and make the rains fall. One participant from Shagarab site said that, "the presences of trees in their landscape protect the camps each year during the dry season from the strong dusty winds and dust". He added that "areas near the AF plots have pleasant climate, good moisture, shade and lower temperature compared to areas that have no trees".

Soil improvement: Participants mentioned that soil fertility in their AF plots have increased particularly after the planted trees have grown up and their crop yields have improved. This is in agreement with [34] who noted that trees improve soil properties in various ways and via several processes. These processes can be summarizes into three categories: 1) increased supply of nutrients through increased inputs and reduced outputs, 2) increased 
availability of nutrients through enhanced nutrient cycling and conversion of nutrients to more labile forms; and 3) improved soil chemical and physical properties conducive for more favorable environment for plant growth.

Erosion control: Participants said that with the current expansion of rain fed agriculture and deforestation for other purposes (firewood and charcoal) the land escape are severely eroded. Local people perceived that land clearing for commercial agricultures poses threat to the stability of seasonal water courses. Participants in Hawata said that this season 2013, they have many difficulties to reach their AF plots because of flooding. They added that not only this but flooding have caused a lot of damage to their crops and newly planted seedlings. It is unanimously mentioned in the literature that AFS can bring more benefits to farmers and landscape over sole cropping due to better soil protection. Soil erosion declines with the increase in vegetative cover. In the early year of the agroforestry system, the intercrop of annual crops helps to increase vegetation cover over land. Several researchers (e.g. [20] [29] [35] have noted that the inclusion of trees in farming systems in the watersheds areas can help: 1) mitigate the damaging effects of soil erosion for local as well as downstream residents, and provide a more regular flow of ground water, 2) reduce siltation downstream, which aid to improve the serving capacity of downstream irrigation systems and thus, the agricultural output in the lowlands. The study area has many seasonal water courses and streams which have been exploited for drinking and irrigation water, hence planting of trees in AF will contribute significantly to improved water quality and quantity, and 3) mitigate flood damage to agriculture lands and infrastructure downstream.

Aesthetic and recreation values: Relative to other ecosystem services, these values are most dependent on the tastes and preferences of the local population. In answering the question "How important is to obtain aesthetic and ornamentation benefits from your AF plot?" Participants in the four sites valued the beauty of the AF plots. The majority (90\%) of respondents reported that AF plots are invaluable to them. Participants from Shagarab and Kilo 26 sites have reported that "the beauty of the landscape in their area has changed over the years due to tree planting and have commended the way agroforestry systems in the project sites are being managed".

Then, the willingness to pay was explored in the study and Table 6 shows that about $90 \%$ of respondents from Shagarab and Kilo 26 would be willing to pay $21 \%$ of their annual income to obtain aesthetic and recreation benefits from AF plots, while 20\% in Mefaza and 30\% Hawata would be willing to pay only 6\% of their annual income. The underlying differences could be attributed to the location of AF plots which are close to residential sites in refugee sites (Shagarab and Kilo 26) compared with those in Mefaza and Hawata sites. Annual incomes per household in the four sites are presented in Table 2.

Besides delivering goods for markets, such as food, wood, fiber and fuel, agroforestry systems also provide non-market services, such as recreation and amenity values, habitats for biodiversity, landscape maintenance and several regulation services [7] [19] [20] [24]. Agroforestry systems, composed by trees, agricultural crops and/or animal production have the potential to enhance soil fertility, reduce soil erosion, improve water quality, enhance biodiversity, maintain and increase aesthetics and sequester carbon [7] [23]. Other rural spaces with non-agricultural land uses, for example wetlands and woodlands, also deliver multiple services including habitat provision, pollinators and recreation [7] [36] [37].

\subsection{Local Perceived TEV of AFS: Relative Importance of Marketable and Non-Marketable Values}

To estimate local perceived TEV of AFS participants were asked to give scores to the 8 direct benefits and 5 services discussed previously (Table 7). Participants were given equal chances to assign scores from 1 - 5 according to the perceived relative importance to investigate the relative weight of the identified goods and services.

Table 7 shows that participants gave higher weight to the marketable direct use values (124 scores) than the

Table 6. Percentage of respondents and percentage income willing to pay.

\begin{tabular}{ccc}
\hline Project sites & \% Respondents & \% income willing to pay \\
Mefaza & 20 & 6 \\
Hawata & 30 & 6 \\
Shagarab & 90 & 21 \\
Kilo 26 & 90 & 21 \\
\hline
\end{tabular}


Table 7. Total scores and ranks of locally perceived TEV of AFS in the project sites.

\begin{tabular}{|c|c|c|c|c|c|c|}
\hline \multirow{2}{*}{$\begin{array}{l}\text { Value categories } \\
\text { Marketable values }\end{array}$} & \multicolumn{3}{|c|}{ Project sites } & \multirow[b]{2}{*}{ Kilo 26} & \multirow{2}{*}{ Total scores } & \multirow{2}{*}{ Ranks } \\
\hline & Mefaza & Hawata & Shagarab & & & \\
\hline Food crops (sorghum) & 5 & 5 & 5 & 5 & 20 & 1 \\
\hline Cash crops & 5 & 4 & 2 & 5 & 16 & 5 \\
\hline Firewood & 4 & 3 & 5 & 5 & 17 & 4 \\
\hline Gum Arabic & 5 & 5 & 5 & 3 & 18 & 3 \\
\hline Livestock feed (crop fodders) & 4 & 5 & 5 & 5 & 19 & 2 \\
\hline NTFPs & 4 & 4 & 4 & 3 & 15 & 6 \\
\hline Honey & 0 & 0 & 0 & 5 & 5 & 13 \\
\hline Traditional medicine & 4 & 3 & 4 & 3 & 14 & 7 \\
\hline Sub-total & & & & & 124 & \\
\hline \multicolumn{7}{|l|}{ Non-marketable uses } \\
\hline Shade & 2 & 3 & 4 & 4 & 13 & 8 \\
\hline Environmental improvement and protection & 2 & 3 & 4 & 3 & 12 & 9 \\
\hline Soil improvement & 2 & 1 & 3 & 2 & 8 & 11 \\
\hline Erosion control & 2 & 2 & 2 & 1 & 7 & 12 \\
\hline Aesthetic and recreation & 1 & 2 & 4 & 4 & 11 & 10 \\
\hline Sub-total & & & & & 74 & \\
\hline
\end{tabular}

non-marketable social and environmental values (74 score) of the AFS, except for honey. This product is not widely practiced in the project sites, but recently introduced to Kilo 26 as an income generating activity. Generally, the participants emphasized that the marketable products from AFS have direct consumptive values which satisfy their immediate needs for sustaining their livelihoods.

The local perceived TEV of AFS includes marketable and non-marketable good and services. The ranking of perceived TEV was derived using grand total values of sample scores of the study. A comparative analysis of the various products was made using the monetary values of the direct used products from section (3.3.1) and qualitative indirect used values described in section (3.3.2). Based on findings from the four sites, Table 8 shows the extrapolated estimation of total direct major use values per year for all participating farmers in project sites.

Table 9 indicates the types of locally perceived TEV of goods and services. According to the ranking of perceived TEV the table shows that the values of all non-marketable benefits perceived by local communities have values greater than that of honey (SDG 32,000.0) at local level. This suggests that their values accrue at least (SDG 160,000.0) to local economy. This is in line with de Groot and van der Meer [10] who concluded that a better understanding of the quantity and value of the goods and services provided by agroforestry or any planted forests enables improved policymaking and management of degraded forested areas. They further suggested that turning this into a "real" money value through pay ecosystems services (PES) schemes can help to pay for the conservation, restoration and sustainable use of a forest area. These new policies and action plans are needed urgently to help restore a wide range of ecosystem services in the large area of degraded forest land in the tropics [10].

Although it is a simple ecosystem, agroforestry systems in the project sites are renewable and capable of providing a wide range of economic, social, environmental and cultural benefits. They supply various products and services, which contribute directly to the well-being of people and are vital to the economy and the environmental conditions of the region. While their essential roles are increasingly recognized by the respondents in the project sites, their benefits and functions are differently valued by policy makers. This is in line with [3] who stated that policy makers often do not perceive and value these services due to the lack of information about the market prices that reflect the monetary value they provide. 
Table 8. Extrapolated annual direct use values (SDG) for total participating households in the project sites.

\begin{tabular}{|c|c|c|c|c|c|c|}
\hline \multirow{2}{*}{ Direct use products } & \multicolumn{4}{|c|}{ Project sites } & \multirow{2}{*}{ Average } & \multirow{2}{*}{$\begin{array}{c}\text { Total for } \\
\text { households in } \\
\text { project sites }\end{array}$} \\
\hline & Mefaza & Hawata & Shagarab & Kilo 26 & & \\
\hline Food crops & 2512.5 & 2512.5 & 2250.0 & 2250.0 & 2381.3 & $952,520.0$ \\
\hline Cash crops & 6300.0 & 7000.0 & 0.0 & 0.0 & 3325.0 & $1,330,000.0$ \\
\hline Firewood & 1200.0 & 1050.0 & 1500.0 & 1350.0 & 1275.0 & $510,000.0$ \\
\hline Gum Arabic & $11,000.0$ & 8800.0 & 7700.0 & 220.0 & 6930.0 & $2,772,000.0$ \\
\hline Livestock feed & 4125.0 & 4125.0 & 3583.5 & 4275.0 & 4027.1 & $1,610,840.0$ \\
\hline NTFPs & 300.0 & 400.0 & 500.0 & 150.0 & 337.5 & $135,000.0$ \\
\hline Honey & 0.0 & 0.0 & 0.0 & 320.0 & 80.0 & $32,000.0$ \\
\hline Traditional medicine & 4.4 & 6.8 & 12.3 & 13.0 & 9.1 & 3640.0 \\
\hline Total (SDG) & $25,441.9$ & $23,894.3$ & $15,545.8$ & 8578.0 & $18,365.0$ & $7,346,000.0$ \\
\hline Total (US\$) & & & & & & $1,669,525.0$ \\
\hline
\end{tabular}

Table 9. Comparison of value ranking for marketable and non-marketable products.

\begin{tabular}{|c|c|c|c|}
\hline Type & $\begin{array}{l}\text { Total } \\
\text { Scores }\end{array}$ & $\begin{array}{c}\text { Ranks of } \\
\text { perceived TEV }\end{array}$ & $\begin{array}{l}\text { Monetary values of direct used } \\
\text { products (SDG) }\end{array}$ \\
\hline \multicolumn{4}{|l|}{ Marketable values } \\
\hline Food crops (sorghum) & 20 & 1 & $952,520.0$ \\
\hline Cash crops & 16 & 5 & $1,330,000.0$ \\
\hline Firewood & 17 & 4 & $510,000.0$ \\
\hline Gum Arabic & 18 & 3 & $2,772,000.0$ \\
\hline Livestock feed (crop fodders) & 19 & 2 & $1,610,840.0$ \\
\hline NTFPs & 15 & 6 & $135,000.0$ \\
\hline Honey & 5 & 13 & $32,000.0$ \\
\hline Traditional medicine & 14 & 7 & 3640.0 \\
\hline Sub-total & 124 & & $7,346,000.0$ \\
\hline \multicolumn{4}{|l|}{ Non-marketable uses } \\
\hline Shade & 13 & 8 & 0.0 \\
\hline Environmental improvement & 12 & 9 & 0.0 \\
\hline Soil improvement & 8 & 11 & 0.0 \\
\hline Erosion control & 7 & 12 & 0.0 \\
\hline Aesthetic and recreation & 11 & 10 & 0.0 \\
\hline Sub-total (SDG) & 74 & & $7,346,000.0$ \\
\hline Sub-total (US\$) & & & $1,669,525.0$ \\
\hline
\end{tabular}

\section{Conclusions}

Agroforestry systems, whether rain fed or irrigated, play an important role in the provision of NPs \& S to local communities in the project sites in Eastern Sudan, as in many other parts of the world. The observed variation in quantities and values of utilized NPs \& S between projects' sites is probably determined by the differences in types of AFS, its components and proximity of the plots from residential area. Overall, from economic point of view the 
AFS in the study sites provided farmers with marketable and sustainable high value products such as food, cash crops, firewood, gum, fodder, NTFPs, medicine, fodder, and honey. Altogether these products provide sustainable income to the farmer directly and also sustainable benefits to the region indirectly. The current study showed that AFS in the project sites contribute economical values greater than SDG 7,346,000.0 (1,335,636.36 US\$) per households per year for quantified marketable goods. This would be many time higher if other indirect values (non-marketable) services such as shade, aesthetic and recreation, environmental protection, biodiversity and carbon sequestration are quantified.

The study provides evidence that the high local values of AFS in the study sites constitute a central means of livelihood and also their contributions to the local economy justify its promotion in the region. The study stresses that there is an essential need to quantify the monetary values of non-marketed products to reliably account for resource accessibility and usage to further sound policy decisions. Except for small-scale irrigated plots, AFS in the project sites was basically rain-fed systems with low production inputs. Tenure security, farmer support services and human capital development were major challenges hindering small-scale farmers from adopting agroforestry in the study sites.

\section{Acknowledgements}

This paper is an output from a consultancy report prepared by the author and funded by IUCN Eastern and Southern African Regional Office (EASARO) under Contract No. ESARO/77174-030/1448 "Economic valuation and market chain analysis for selected products from Agroforestry systems". The views expressed in this paper are not necessarily those of ESARO/77174-030/1448. The authors acknowledge the research assistance of IUCN/ESARO. Many thanks for Mr. Mahmoud Awad Mekki for his cooperation during the field work and data analysis. The assistance we received from the Project staff at El Fau, Hawata and Gedarif is highly appreciated.

\section{References}

[1] Barbier, E.B., Acreman, M. and Knowler, D. (1997) Economic Valuation of Wetlands: A Guide for Policy Makers and Planners. Ramsar Convention Bureau, Gland.

[2] Lette, H. and de Boo, H. (2002) Economic Valuation of Forests and Nature: A Support Tool for Effective DecisionMaking. Wageningen: International Agricultural Center, 2002. Series Forests, Forestry and Biodiversity Support Group 6.

[3] Rasul, G. (2009) Ecosystem Services and Agricultural Land-Use Practices: A Case Study of the Chittagong Hill Tracts of Bangladesh. Sustainability: Science, Practice, \& Policy, 5, 15-27.

[4] Barbier, E.B. (2007) Valuing Ecosystem Services as Productive Inputs. Economic Policy, 22, 177-229. http://dx.doi.org/10.1111/j.1468-0327.2007.00174.x

[5] Barbier, E.B. (2009) Ecosystems as Natural Assets. Foundations and Trends in Microeconomics, 4, 611-681. http://dx.doi.org/10.1561/0700000031

[6] MEA, Millennium Ecosystem Assessment (2005) Ecosystems and Human Well-Being: Our Human Planet: Summary for Decision Makers. The Millennium Ecosystem Assessment Series, Volume 5, Island Press, Washington DC.

[7] Buckwell, A. (2009) Public Goods from Private Land. Rural Investment Support for Europe (RISE) Foundation, Brussels. www.risefoundation.eu

[8] Sukhdev, P. (2010) TEEB-Mainstreaming the Economics of Nature: A Synthesis of the Approach, Conclusions and Recommendations of TEEB. http://teebweb.org

[9] Fisher, B., Turner, R.K. and Morling, P. (2009) Defining and Classifying Ecosystem Services for Decision Making. Ecological Economics, 68, 643-653. http://dx.doi.org/10.1016/j.ecolecon.2008.09.014

[10] de Groot, R.S. and van der Meer, P.J. (2010) Quantifying and Valuing Goods and Services Provided by Plantation Forests. In: Bauhus, J., van der Meer, P.J. and Kanninen, M., Eds., Ecosystem Goods and Services from Plantation Forests. Earthscan, London, Washington DC, 255.

[11] Costanza, R., d’Arge, R., de Groot, R., Farber, S., Grasso, M., Hannon, B., Limburg, K., Naeem, S., O’Neill, R.V., Paruelo, J., Raskin, R.G., Sutton, P. and van den Belt, M. (1997) The Value of the World's Ecosystem Services and Natural Capital. Nature, 387, 253-260. http://dx.doi.org/10.1038/387253a0

[12] Daily, G.C. (1997) Introduction: What Are Ecosystem Services? In: Daily, G.C., Ed., Nature’s Services: Societal Dependence on Natural Ecosystems, Island Press, Washington DC, 1-10.

[13] Landell-Mills, N. and Porras, I. (2002) Silver Bullet or Fools’ Gold? A Global Review of Markets for Forest Environ- 
mental Services and Their Impacts on the Poor. IIED, London. http://www.worldagroforestrycentre.org/sea

[14] Sileshi, G., Akinnifesi, F.K., Ajayi, O.C., Chakeredza, S., Kaonga, M. and Matakala, P.W. (2007) Contributions of Agroforestry to Ecosystem Services in the Miombo Eco-Region of Eastern and Southern Africa. African Journal of Environmental Science and Technology, 1, 68-80. http://www.academicjournals.org/AJest

[15] Wunder, S. (2005) Payments for Environmental Service, Some Nuts and Bolts. CIFOR CIFOR Occasional Paper No. 42.

[16] Pagiola, S., von Ritter, K. and Bishop, J. (2004) Assessing the Economic Value of Ecosystem Conservation. The World Bank Environment Department, Paper No. 101.

[17] Dixon, J. and Pagiola, S. (1998) Economic Analysis and Environmental Assessment. Environmental Economics and Indicators Unit, Environment Department. EA Sourcebook Update.

[18] Kumar, B.M. and Nair, P.K.R. (Eds.) (2011) Carbon Sequestration Potential of Agroforestry Systems: Opportunities and Challenges. Advance in Agroforestry, Vol. 8, National and International Policy Makers-Summary: Responding to the Value of Nature, Springer, Dordrecht.

[19] ICRAF (2006) World Agroforestry Centre, Southeast Asia Web Site.

[20] Jose, S. (2009) Agroforestry for Ecosystem Services and Environmental Benefits: An Overview. Agroforestry Systems, 76, 1-10. http://dx.doi.org/10.1007/s10457-009-9229-7

[21] Idol, T., Haggar, J. and Cox, L. (2011) Ecosystem Services from Smallholders Forestry and Agroforestry in the Tropics. In: Campbell, W.B. and Ortiz, S.L., Eds., Integrating Agriculture, Conservation and Ecotourism: Examples from the Field, Issues in Agro-Ecology-Present Status and Future Prospectus, Vol. 1, Springer, Dordrecht, 209-270. http://dx.doi.org/10.1007/978-94-007-1309-3_5

[22] Leakey, R.R.B. (1996) Definition of Agroforestry Revised. Agroforestry Today, 8, 5-7.

[23] Garrity, D.P. (2004) Agroforestry and the Achievement of the Millenium Development Goals. Agroforestry Systems, 61, 5-17. http://dx.doi.org/10.1023/B:AGFO.0000028986.37502.7c

[24] Porter, J., Costanza, R., Sandhu, H., Sigsgaard, L. and Wratten, S. (2009) The Value of Producing Food, Energy, and Ecosystem Services within an Agro-Ecosystem. AMBIO: Journal of the Human Environment, 38, 186-193. http://dx.doi.org/10.1579/0044-7447-38.4.186

[25] Franzel, S. and Scherr, S.J. (2002) Trees on the Farm: Assessing the Adoption Potential of Agroforestry Practices in Africa. CABI Publishing, Wallingford. http://dx.doi.org/10.1079/9780851995618.0000

[26] Harrison, M.N. and Jackson, J.K. (1958) Ecological Classification of the Vegetation of the Sudan. Forest Bulletin No. 2, Agriculture Publications Committee, Khartoum.

[27] El Tayeb, G. and Osman, H.M.E.M. (2011) Land Tenure and Baseline Study for the Project: Securing Rights and Restoring Lands for Improved Livelihoods Kassala and Gedaref States-Sudan (Final Report).

[28] Barbier, E.B., Baumgärtner, S., Chopra, K., Costello, C., Duraiappah, A., Hassan, R., Kinzig, A., Lehman, M., Pascual, U., Polasky, S. and Perrings, C. (2009) The Valuation of Ecosystem Services. (Chapter 18). In: Naeem S., Bunker, D., Hector, A., Loreau, M. and Perrings, C., Eds., Biodiversity, Ecosystem Functioning, and Human Wellbeing: An Ecological and Economic Perspective, Oxford University Press, Oxford, 248-262. http://dx.doi.org/10.1093/acprof:oso/9780199547951.003.0018

[29] Young, A. (1989) Agroforestry for Soil Conservation. CAB International, Wallingford. Nair, P.K.R. (2011) Agroforestry Systems and Environmental Quality: Introduction. Journal of Environmental Quality, 40, 784-790. http://dx.doi.org/10.2134/jeq2011.0076

[30] Ruiz Perez, M., Belcher, B., Achdiawan, R., Alexiades, M., Aubertin, C., Caballero, J., Campbell, B., Clement, C., Cunningham, A., Fantini, de Foresta, H., Fernandez, C.G., Guatam, K., Hersch Martinez, P., de Jong, W., Kusters, K., Kutty, M.G., Lopez, C., Fu, M., Nair, T.K.R., Ndoye, O., Ocampo, R., Rai, N., Ricker, M., Schrechemberg, K., Shackleton, S., Shanley, P., Sunderland, T. and Youn, Y. (2004) Markets Drive the Specialization Strategies of Forest People. Ecology and Society, 9, 4.

[31] Sanchez, P.A. (1995) Science in Agroforestry. Agroforestry Systems, 30, 5-55. http://dx.doi.org/10.1007/BF00708912

[32] Denning, G.L. (2001) Realizing the Potential of Agroforestry: Integrating Research and Development to Achieve Greater Impact. Development in Practice, 11, 407-416. http://dx.doi.org/10.1080/09614520120066693

[33] IIED (1997) Valuing the Hidden Harvest: Methodological Approaches for Local-Level Economic Analysis of Wild Resources. Sustainable Agriculture Programme Research Series, Vol. 3, International Institute for Environment and Development (IIED), London, 71.

[34] Buresh, R.L. and Tian G. (1998) Soil Improvement by Trees in Sub-Saharan Africa. Agroforestry Systems, 38, 51-76. http://dx.doi.org/10.1023/A:1005948326499

[35] Kaonga, M.L. (2012) Agroforestry for Biodiversity and Ecosystems Services: Science and Practices. In Tech, Rijeka. 
[36] Posthumus, H., Rouquette, J.R., Morris, J., Gowing, D.J.G. and Hess, T.M. (2010) A Framework for the Assessment of Ecosystem Goods and Services; a Case Study on Lowland Floodplains in England. Ecological Economics, 69, 15101523. http://dx.doi.org/10.1016/j.ecolecon.2010.02.011

[37] Farley, J. and Costanza, R. (2010) Payments for Ecosystem Services: From Local to Global. Ecological Economics, 69, 2060-2068. http://dx.doi.org/10.1016/j.ecolecon.2010.06.010 